\title{
RODENT ANIMAL MODELS OF DELAYED BONE HEALING AND NON-UNION FORMATION: A COMPREHENSIVE REVIEW
}

P. Garcia ${ }^{1, *}$, T. Histing 2 , J.H. Holstein ${ }^{2}$, M. Klein ${ }^{2}$, M.W. Laschke 6 , R. Matthys ${ }^{3}$, A. Ignatius ${ }^{4}$, B. Wildemann ${ }^{5}$, J. Lienau ${ }^{5}$, A. Peters 5 , B. Willie ${ }^{5}$, G. Duda ${ }^{5}$ L. Claes 5 , T. Pohlemann ${ }^{2}$ and M.D. Menger ${ }^{6}$

\author{
${ }^{1}$ Department of Trauma-, Hand- and Reconstructive Surgery, University Hospital Muenster, Münster, Germany \\ ${ }^{2}$ Department of Trauma-, Hand- and Reconstructive Surgery, University of Saarland, Homburg/Saar, Germany \\ ${ }^{3} \mathrm{AO}$ Research Institute, Davos, Switzerland \\ ${ }^{4}$ Institute for Orthopaedic Research and Biomechanics, University of Ulm, Germany \\ ${ }^{5}$ Julius Wolff Institute, Center for Musculoskeletal Surgery, Berlin-Brandenburg Center for Regenerative Therapies, \\ Chariteé-Universitätsmedizin Berlin, Berlin, Germany \\ ${ }^{6}$ Institute for Clinical \& Experimental Surgery, University of Saarland, Homburg/Saar, Germany
}

\begin{abstract}
Despite the growing knowledge on the mechanisms of fracture healing, delayed healing and non-union formation remain a major clinical challenge. Animal models are needed to study the complex process of normal and impaired fracture healing and to develop new therapeutic strategies. Whereas in the past mainly large animals have been used to study normal and impaired fracture healing, nowadays rodent models are of increasing interest. New osteosynthesis techniques for rat and mice have been developed during the last years, which allowed for the first time stable osteosynthesis in these animals comparable to the standards in large animals and humans. Based on these new implants, different models in rat and mice have been established to study delayed healing and non-union formation. Although in humans the terms delayed union and non-union are well defined, in rodents definitions are lacking. However, especially in scientific studies clear definitions are necessary to develop a uniform scientific language and allow comparison of the results between different studies. In this consensus report, we define the basic terms "union", "delayed healing" and "non-union" in rodent animal models. Based on a review of the literature and our own experience, we further provide an overview on available models of delayed healing and non-union formation in rats and mice. We further summarise the value of different approaches to study normal and delayed fracture healing as well as non-union formation, and discuss different methods of data evaluation.
\end{abstract}

Keywords: Fracture healing; bone healing; rodents; mice; rats; union; non-union; delayed healing; critical size defect.

\footnotetext{
*Address for correspondence:

P. Garcia

Department of Trauma-, Hand- and Reconstructive Surgery University Hospital Muenster

D-48308 Muenster, Germany

Telephone Number: +49-251-83-59231

E-mail: patric.garcia@ukmuenster.de
}

\section{Background}

Despite the growing knowledge on the mechanisms of fracture healing, delayed healing and non-union formation remain a clinical problem. Delayed unions and especially non-unions do not only result in significant pain and loss of function with subsequent reduction in quality of life, but are also associated with a considerable economic burden to the society (Victoria et al., 2009). Many strategies have been described to treat non-unions, but there is still no consensus on the ideal management. Autologous bone grafts are still considered as the gold standard (Hayda and Bosse, 2006). However, autologous bone grafts can be associated with a high donor site morbidity (Laurie $e t$ al., 1984) and the amount of the graft material is limited, especially if previous harvests have been performed. Great inter-individual differences in the quality of the graft material and failure rates of up to $60 \%$ are further limitations of this technique (Wheeler and Enneking, 2005). Although some new pharmacological approaches, such as growth factor treatment with BMP-2 (Infuse ${ }^{\circledR}$, Medtronic, Fridley, MN, USA) and BMP-7 (Osigraft ${ }^{\circledR}$, Stryker Biotech, Hopkinton, MA, USA), have been successfully applied to treat non-unions, they have not been proven superior to the use of autografts in randomised comparative clinical trials (Obert et al., 2005). Therefore, there is still a great need for the development and evaluation of new treatment strategies to stimulate bone healing especially in patients with non-unions.

To study the pathophysiology of delayed fracture healing and non-union formation, appropriate animal models are needed. These animal models should be well standardised and, most importantly, should approximate the clinical situation in humans. Only studies using appropriate models will contribute to a better understanding of the mechanisms of the disease and will assist in the development of novel therapeutic strategies. Accordingly, not every animal model with a fracture that does not adequately heal may be suitable to study nonunion formation.

In March 2010 a Medline search (http://www.pubmed. com) was performed using the search term "fracture healing" with limitation to "animal model". The results were differentiated to "mouse" models, "rat" models and other animal fracture models. The Medline search indicates that the number of experimental fracture healing studies increased from 40 studies per year in 1980 to 255 


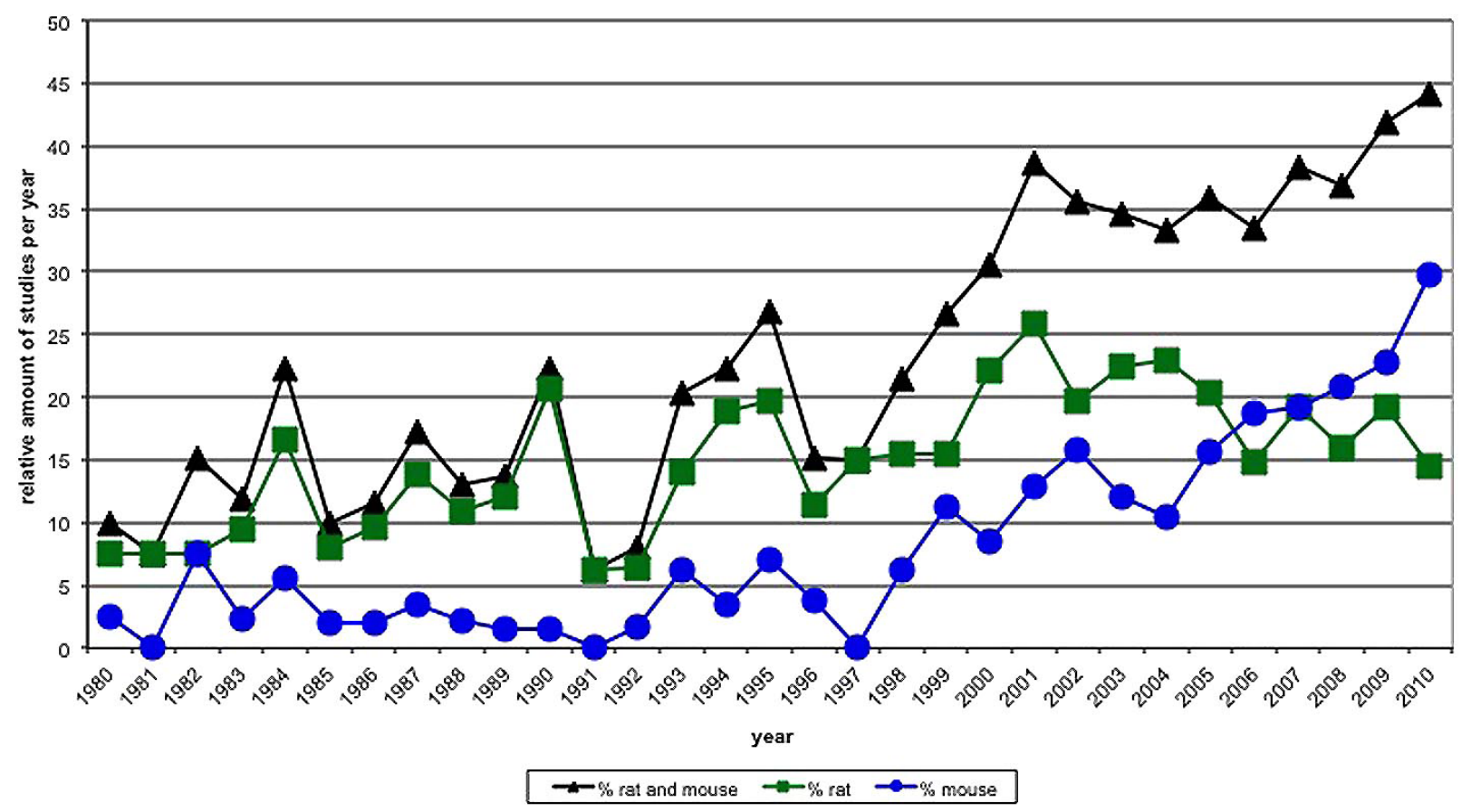

Fig. 1. Percentage of studies using mouse and rat fracture models of all studies reporting animal fracture experiments per year between 1980 and 2010. The proportion of mouse and rat fracture models steadily increased and in 2010 almost half of all experimental studies using animal fracture models have been performed in these animals (45\%). Of

studies per year in 2009. Whereas in the past mainly large animals, like sheep, dog and rabbits, have been used to analyse fracture healing (Volpon, 1994; Oni, 1995; Den Boer et al., 1999; Brownlow et al., 2002; Arinzeh et al., 2003), later, animal models using rats and mice came into the focus of fracture research. Over recent years, the relative number of fracture healing studies using rats and mice steadily increased and currently almost half of all animal fracture studies are conducted in mice or rats (45\%) (Fig. 1). In fact, mice and rats are of special interest to study the molecular aspects of bone healing due to the great availability of genetically modified strains and biomedical tools, like antibodies, primers etc.. In addition, breeding and husbandry of these animals is faster and easier with significantly reduced costs. Moreover, most experimental interventions in mice and rats can be performed by one investigator, whereas in larger animals like sheep more personnel are required for the surgical interventions and the husbandry. These factors allow the analyses of a greater number of rats and mice in shorter time periods compared to larger animals. Of interest, until 2005 most murine fracture studies have been conducted in rats, whereas after 2007 the number of fracture healing studies in mice exceeds that of rats (Fig. 1).

The number of fracture healing studies in rats and mice increased over the last 30 years. However, the number of fracture studies on delayed healing and non-union formation increased only during the last few years. This is probably because of greater difficulties in the development of standardised and reliable models of delayed healing and non-union formation, since rats and mice have a great healing capacity as animals of a lower phylogenetic scale. In mice and rats, even fractures with poor mechanical fixation or no fixation at all heal without a significant delay of bone union (Manigrasso and O'Connor, 2004; Lu et al., 2008).

Only recent developments of sophisticated osteosynthesis techniques in mice and rats allow a rigid stabilisation of segmental defects. These developments resulted in an increasing number of rat and mice models, to study delayed fracture healing and non-union formation (Thompson et al., 2002; Garcia et al., 2008b). Because of the increasing importance of mouse and rat models of delayed healing and non-union formation, we discussed this issue at a symposium held in 2010 at the monastery Hornbach in Germany and summarise this discussion in the following consensus report. The aim of this report is to give an overview and to define the standards of current models of delayed union and non-union formation in rats and mice.

\section{Definition of fracture union, delayed union and non- union}

To develop standards for experimental studies on fracture healing, clear definitions of union, delayed healing and non-union are required. Furthermore, a segmental defect and a critical size defect (CSD) must be defined. Unfortunately, current definitions are not consistent throughout the literature.

\section{Union}

In general, union is defined as the structural adhesion of the edges of two or more bodies. During fracture healing, union indicates the renewal of the bony continuity in the 
Table 1. Definition of fracture union, delayed union, non-union and critical size defect in mouse and rat animal fracture models.

\begin{tabular}{|l|l|}
\hline Bone union & $\begin{array}{l}\text { The first bridging of the fracture gap by bone tissue in histological } \\
\text { or micro-CT analysis }\end{array}$ \\
\hline Delayed union & Delay in bone bridging compared to an adequate control group \\
\hline Non-union & $\begin{array}{l}\text { Failure of bone bridging in the rat after } 15 \text { weeks and in the mouse } \\
\text { after } 12 \text { weeks. }\end{array}$ \\
\hline Critical size defect (CSD) & Segmental bone defect leading to non-union \\
\hline
\end{tabular}

fractured bone. Clinically, the course of fracture healing is monitored radiologically. In contrast, fracture research in animal models offers more sophisticated techniques to analyse bone healing and union. These should be applied to determine the time point of union. Histological and microCT analyses are most suitable and should be included whenever the time point of union has to be determined. For animal studies, we define the time point of bone union as the first bridging of the fracture gap by bone tissue (Table 1). For the determination of bone union, osseous bridging of the whole circumference is not necessary. At this time point the callus still has a poor mechanical competence and the process of healing is still ongoing. However, the bony continuity is re-established and fracture healing will regularly proceed if no further intervention is performed. We think that later time points are less suitable to define a union in rodent fracture models, because it is hardly possible to choose a reasonable time point between first bone bridging and completion of the remodelling process. We are aware that other definitions are currently also used to define the time point of union, which additionally include the process of callus remodelling. However, we think that the exact determination of such a time point is more difficult, because of the lack of defined stages of remodelling. In general, we strongly suggest that the exact definition of union should always be given in the methods section of a study. To temporally delineate the individual stages of fracture healing, we also recommend that both morphological and biomechanical analyses are performed. These should be performed in a standardised fashion as described previously in detail (Vashishth, 2008), which will facilitate the comparison of data between different studies.

\section{Delayed union}

The definition of delayed healing is much more complex, because bone healing is a continuous process that is influenced by several factors. Bone healing begins with soft callus formation and is followed by hard callus formation, which leads to bone bridging of the bone fragments, and is completed with remodelling of the bone architecture. In this continuum, specific stages can be delayed for example soft callus formation, but can be compensated during the later time course by acceleration of hard callus formation or remodelling (Claes et al., 2006; Garcia et al., 2008a; Grongroft et al., 2009). Therefore, it is of great importance that in an animal model of delayed union several time points are analysed to detect alterations during the different stages of fracture healing.
This should be done by morphometrical and biomechanical analyses. In most rodent models, especially the mouse, a periosteal callus is formed with initial bone bridging at the outer diameter of the fracture. As bone bridging of the fracture gap proceeds, torsional stiffness increases to $30-100 \%$ compared to unfractured bone. Of interest, torsional stiffness may exceed $100 \%$ after circumferential bone bridging at the outer diameter of the periosteal callus due to the increased cross sectional area compared to unfractured bone (Garcia et al., 2008a). The torsional stiffness then decreases again to $100 \%$ of unfractured bone, as bone remodelling proceeds. Thus, because torsional stiffness may be similar during early circumferential bone bridging and after bone remodelling, the biomechanical analysis alone is not sufficient to determine the stage of bone healing. Only additional morphometrical analysis makes it possible to discriminate between different stages of bone healing. On the other hand, morphometry alone does not allow any conclusion on the biomechanical competence, because intrinsic material properties of the healing bone are unknown. Thus, we recommend that analysis of fracture healing must include both, biomechanical and morphometrical analysis.

Because normal healing is influenced by several parameters and can vary between different fracture models these parameters should also be considered when comparing different animal models of delayed union. The most important parameters which may be responsible for differences in fracture healing between different mouse and rat fracture models are: (i) the osteosynthesis technique, including the effects of surgery (closed fracture $v s$. osteotomy) and rigidity of stabilisation (Histing et al., 2010), (ii) the animal strain (Manigrasso and O'Connor, 2008) as well as (iii) the age and the sex of the animals (Lu et al., 2008; Mehta et al., 2011). Therefore, information about these basic parameters should always be given in the methods section of studies using an animal fracture model.

Because multiple parameters influence bone healing, specific time points are not suitable to define a delayed union. A delayed union could therefore better be defined as a delay in bone bridging compared to an adequate control group (Table 1).

\section{Non-union}

Non-union is the permanent failure of bone healing. It is characterised by complete cessation of periosteal and endosteal bone formation with scar formation in the fracture gap. A non-union, as per definition, does not heal throughout the lifetime of the animal if left alone. 
For clinical use, the definition of a certain time point is required that enables rational management decisions. In humans, a time period of 6 months has been accepted to define a non-union. Considering a normal healing time of 8 weeks in human long bones, this is almost 3-times that required for normal fracture healing. According to the human definition, we define a non-union in rats as failure of bone healing after 15 weeks and in mice after 12 weeks (Table 1), representing also 3-times that required for normal fracture healing (Fig. 2). These definitions are in line with previously described non-union models in rats and mice, showing a lack of adequate healing after these time periods (Garcia et al., 2008b; Burastero et al., 2010). For the characterisation of a rodent non-union model, we recommend that bone healing be analysed after 2, 4, 8 and 12 weeks in mice and after 2, 5, 10 and 15 weeks in rats to confirm the cessation of the bone healing process. However, these time points are arbitrary and other time points may also be suitable to demonstrate that there is no progressive bone healing.

Every rodent non-union model must clearly discriminate between atrophic and hypertrophic non-unions. This is of great importance, because the underlying pathologies are different. An atrophic non-union is characterised by sparse callus formation and sclerosis of the medullary canal with only fibrous tissue filling the fracture gap. In contrast, a hypertrophic non-union is characterised by a large callus formation and endochondral bone formation at the fracture ends. In addition, in humans a pseudarthrosis is defined as a special form of a non-union with false joint formation and establishment of a synovial membrane (Heppenstall et al., 1987). However, in rodents the non-union models reported do not show false joint formation with establishment of a synovial membrane.

\section{Critical size defect (CSD)}

To achieve delayed healing or non-union formation in rodents, most studies created segmental defects after osteotomy. A CSD has been defined as "the smallest intraosseous wound that would not heal spontaneously throughout the lifetime of an animal" (Hollinger and Kleinschmidt, 1990). However, in practice most authors describe CSD models, without systematically analysing the smallest defect which still leads to failure of bone healing. Therefore, we feel it is suitable to simply define a CSD as a defect that leads to a non-union. In fact, CSD models are non-union models, using a segmental defect that exceeds the healing capacity of the normal bone. The size of the CSD depends on the specific model, especially on the phylogenetic scale of the animal. In general, a CSD may be defined as a defect, exceeding 1.5-3.0 times the diameter of the bone (Lindsey et al., 2006; Reichert et al., 2009). However, because many factors influence the process of bone healing, e.g., age, gender, species, strain, soft tissue injury and fracture stabilisation, it is not possible to specify a universal definitive size of a segmental defect in mice or rats as a CSD. Of interest, whereas in most species the size of a CSD decreases with age, the size of CSDs in rats seems to be constant over the whole life span (Hollinger and Kleinschmidt, 1990).

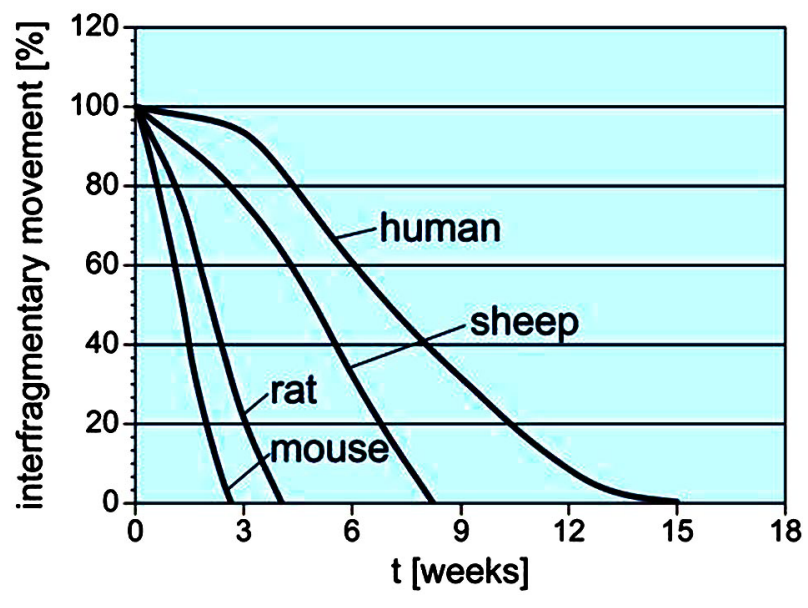

Fig. 2. Comparison of the time course of fracture healing (interfragmentary movement) during fracture healing in mice, rats, sheep and humans.

When a CSD model is designed, we do not recommend the combination of a segmental defect with a soft tissue or periosteal injury. The segmental defect can be created with a Gigli wire saw. When an oscillating saw or a trephine are used, permanent saline cooling to avoid heat necrosis of the adjacent bone may be performed.

\section{Animal models}

Models of delayed fracture healing in mice and rats A model of delayed healing is of interest to study the underlying pathophysiology, but may also serve to analyse the success of novel treatment strategies, aiming at the acceleration of bone healing. Distinct procedures may be applied to delay the process of fracture healing (Table 2). Among these, some may be considered most suitable to achieve delayed healing in a standardised fashion, including (i) segmental defects (Claes et al., 2009), (ii) vascular injury (Utvag et al., 2001; Lu et al., 2007), (iii) periosteal and endosteal injury (Utvag et al., 2001; Dickson et al., 2008), (iv) modification of fixation stiffness (Utvag et al., 2001; Claes et al., 2009) and (v) soft tissue injury (Claes et al., 2006) (Table 3).

Apart from these procedures, delayed fracture healing may also be achieved by inducing metabolic disorders. For example, induction of diabetes mellitus in mice results in delayed fracture healing (Follak et al., 2005; Retzepi and Donos, 2010). Those models may be appropriate to study novel treatment strategies to improve the process of healing under diabetic conditions. However, it should be taken into account that many factors may affect the process of fracture healing without representing models for delayed healing.

The strain of the animal, as well as its sex and age, are known to influence fracture healing. In fact, female mice showed delayed bone healing when compared with male controls, just as well as old animals compared to young controls (Lu et al., 2008). This, however, does not indicate that female mice or old animals can serve as a model of delayed fracture healing. Instead, these studies provide substantial information on the normal physiological 
Table 2. Approaches to influence fracture healing in mice and rats.

\begin{tabular}{|c|c|}
\hline Mechanical approach & Biological approach \\
\hline Osteosynthesis stiffness & Surgical technique (open/closed) \\
\hline Interfragmentary movement & Anatomic localisation of the fracture \\
\hline Lack of fixation & Fracture gap size \\
\hline & Fracture configuration \\
\hline & Periosteal injury \\
\hline & Endosteal injury \\
\hline & Additional soft tissue injuries \\
\hline & Additional vascular injury \\
\hline & Gender and age \\
\hline & Strain specific differences \\
\hline & Metabolic disorders \\
\hline & Pharmacological interventions \\
\hline & Transgenic animals (loss of function) \\
\hline
\end{tabular}

Table 3. Delayed union models in mice and rats.

\begin{tabular}{|c|c|c|c|c|c|}
\hline Authors & $\begin{array}{l}\text { Animal/ } \\
\text { bone }\end{array}$ & Fixation & Fracture model & $\begin{array}{l}\text { Observation } \\
\text { time }\end{array}$ & Delay in healing \\
\hline Kratzel et al. 2008 & $\begin{array}{l}\text { rat/ } \\
\text { tibia }\end{array}$ & $\begin{array}{l}\text { PDLLA coated } \\
\text { titanium wire }\end{array}$ & $\begin{array}{l}\text { tibia osteotomy \& } \\
\text { fibula fracture }\end{array}$ & 12 weeks & $\begin{array}{l}15 \% \text { stiffness of } \\
\text { control }\end{array}$ \\
\hline $\begin{array}{l}\text { Hausman et al. } \\
2001\end{array}$ & $\begin{array}{l}\text { rat/ } \\
\text { femur }\end{array}$ & $\begin{array}{l}\text { pin } \\
\text { intramedullary }\end{array}$ & $\begin{array}{l}\text { closed fracture+ } \\
\text { inhibition of angio- } \\
\text { genesis }\end{array}$ & 3,5 weeks & $\begin{array}{l}20 \% \text { stiffness of } \\
\text { control }\end{array}$ \\
\hline Strube et al. 2008 & $\begin{array}{l}\text { rat/ } \\
\text { femur }\end{array}$ & external fixator & $\begin{array}{l}1.5 \mathrm{~mm} \text { osteotomy \& } \\
\text { semi-rigid fixator }\end{array}$ & 6 weeks & $\begin{array}{l}60 \% \text { stiffness of } \\
\text { control }\end{array}$ \\
\hline Claes et al. 2009 & $\begin{array}{l}\text { rat/ } \\
\text { femur }\end{array}$ & external fixator & $\begin{array}{l}1.0 \mathrm{~mm} \text { osteotomy+ } \\
\text { semi-rigid fixator }\end{array}$ & 5 weeks & $\begin{array}{l}\text { lower flexural } \\
\text { rigidity }\end{array}$ \\
\hline $\begin{array}{l}\text { Dickson et al. } \\
2008\end{array}$ & $\begin{array}{l}\text { rat/ } \\
\text { femur }\end{array}$ & external fixator & $\begin{array}{l}0.0 \mathrm{~mm} \text { osteotomy \& } \\
\text { periosteum caut. \& } \\
\text { endosteum reamed }\end{array}$ & 14 weeks & $\begin{array}{l}40 \% \text { load } \\
\text { of control }\end{array}$ \\
\hline Utvag et al. 2001 & $\begin{array}{l}\text { rat/ } \\
\text { femur }\end{array}$ & $\begin{array}{l}\text { steel wire, } \\
\text { after } 3 \text { weeks } \\
\text { flexible PE nail }\end{array}$ & $\begin{array}{l}\text { manual fracture \& } \\
\text { endosteum reamed }\end{array}$ & 10 weeks & $\begin{array}{l}\sim 40 \% \text { stiffness } \\
\text { of control }\end{array}$ \\
\hline Lu et al. 2007 & $\begin{array}{l}\text { mouse/ } \\
\text { tibia }\end{array}$ & $\begin{array}{l}\text { no fixation or } \\
\text { external fixator }\end{array}$ & $\begin{array}{l}\text { closed fracture \& } \\
\text { no osteosynthesis }\end{array}$ & 3 weeks & $\begin{array}{l}20 \% \text { union } \\
\text { of control }\end{array}$ \\
\hline $\begin{array}{l}\text { Garcia et al. } \\
2008 \mathrm{~b}\end{array}$ & $\begin{array}{l}\text { mouse/ } \\
\text { femur }\end{array}$ & $\begin{array}{l}\text { intramedullar pin \& } \\
\text { extramedullar clip }\end{array}$ & $\begin{array}{l}0.8 \mathrm{~mm} \\
\text { osteotomy }\end{array}$ & 10 weeks & $\begin{array}{l}\sim 30 \% \text { union } \\
\text { of control }\end{array}$ \\
\hline $\begin{array}{l}\text { Garcia et al. } \\
2008 \mathrm{a}\end{array}$ & $\begin{array}{l}\text { mouse/ } \\
\text { femur }\end{array}$ & $\begin{array}{l}\text { intramedullar pin \& } \\
\text { extramedullar clip }\end{array}$ & $\begin{array}{l}0.0 \mathrm{~mm} \text { osteotomy \& } \\
\text { unstable } \\
\text { osteosynthesis }\end{array}$ & 5 weeks & $\begin{array}{l}50 \% \text { stiffness of } \\
\text { control }\end{array}$ \\
\hline
\end{tabular}

variation depending on strain, gender and age, and indicate that these factors must be carefully considered when planning future studies.

A complex fracture configuration is also known to delay fracture healing, but yet it is not possible to reproducibly create complex fractures in mice and rats. Although complex fractures show poor healing and remain a clinical problem, we think that, at the moment, osteotomies or simple transverse and oblique fractures should also be preferred as animal models when studying delayed healing, due to the higher degree of standardisation.

\section{Non-union models in rats}

During the last decade, a considerable number of nonunion models in the rat have been introduced. Most of them were used to analyse new treatment strategies to stimulate fracture healing. Almost all of these studies used a biological approach to impair bone healing (Table 
4) leading to atrophic non-unions. Only Cullinane and coworkers used a mechanical approach with daily bending a $3.0 \mathrm{~mm}$ osteotomy to create a hypertrophic non-union (Cullinane et al., 2002). The models leading to atrophic non-unions can basically be divided into two groups using (i) large segmental defects of 3-8 $\mathrm{mm}$ or (ii) smaller segmental defects up to $3 \mathrm{~mm}$ with an additional periosteal or endosteal injury (Table 4). Although not all of these studies included an observation time of 15 weeks, we think that both approaches are suitable to study atrophic nonunion formation in the rat. However, we do not generally recommend the use of the combined model with a small segmental defect (1-3 mm) and a periosteal or endosteal injury, because the pathophysiology of an atrophic nonunion due to a segmental defect is different from that of an atrophic non-union due to periosteal or endosteal injury. This makes the interpretation of the data difficult, and does not allow comparison of data from different studies. Depending on the aim of the specific study, we recommend the use of a segmental defect model without periosteal or endosteal injury. Alternatively, a simple fracture model with an additional endosteal or periosteal injury, but without a segmental defect, can be used.

Schmidhammer et al. (2006) reported on an atrophic non-union model using a $0.38 \mathrm{~mm}$ osteomy and separation of the bone from the surrounding soft tissue by a silicone membrane. Although this model is not comparable to the human situation of atrophic non-union formation, it is suitable to analyse the role of soft tissue in bone healing. Another interesting model has been introduced by Chen et al., using a segmental defect of $6 \mathrm{~mm}$ in the rat femur in combination with a local Staphylococcus aureus infection (Chen et al., 2005). This is of special interest, because perioperative infections are still a major clinical problem and there is indeed a need for septic non-union models. However, future septic non-union models should not necessarily combine large segmental defects with an infection because differentiation between the effects of the segmental defect and the infection would be difficult. We rather recommend the use of closed fracture models or osteotomy models without segmental defects, in combination with local infection, to study the mechanisms of septic non-union formation.

Non-union models using the radius or the fibula do not need an additional osteosynthesis due to the intrinsic stabilisation by the ulna or tibia. However, both bones are disadvantageous for biomechanical testing due to their small size and their anatomic configuration. Nonunion models using the rat tibia are widely used but have the drawback of the irregular shape of the tibia. The triangular configuration and the bowed longitudinal axis afford a more sophisticated design of the implants, guaranteeing stable fixation. In addition, the biomechanical test accuracy is limited due to the irregular shape of the bone. Although access to the tibia is relatively easy, due to the sparse muscle coverage, this anatomic condition is disadvantageous when analysing the role of soft tissue in bone repair. The last issue that has to be considered when using the tibia in a fracture model is the potential fracture of the fibula, leading to either 2 different calluses or 1 combined callus. Therefore, we think that the femur with its tubular structure and its relatively constant inner and outer diameter is more suitable to study non-union formation in the rat.

Whereas most of the segmental defect models have been performed using stable osteosynthesis techniques (plates, external fixators), some non-union models used a simple intramedullary pin for fracture stabilisation (Hietaniemi et al., 1995; Kokubu et al., 2003). In these models it should be taken into account that a simple intramedullary pin does not provide axial or rotational stability, leading to an uncontrolled biomechanical situation which is not comparable to osteosynthesis procedures in humans. In fact, we strongly suggest that osteosynthesis techniques in the rat should meet the same criteria as osteosynthesis techniques in humans. This includes also the ex vivo characterisation of the implant stiffness of newly developed osteosynthesis devices.

\section{Non-union models in mice}

Because mice are a species on the lower phylogenetic scale, they can develop a great potential for bone repair and even unstabilised fractures can heal without a delay (Colnot et al., 2003). As a consequence, the development of a reproducible non-union model in the mouse is demanding, and, in contrast to rat non-union models, mouse non-union models are sparse (Table 5).

Choi and co-workers were the first to report on a nonunion model in the mouse. They performed an osteotomy of the tibia followed by a distraction procedure with an external fixator (Choi et al., 2004). However, in this model only $60 \%$ of the studied animals showed failure of fracture healing. These $60 \%$ of healing failure may also not be defined as non-unions, because the 27-days observation period chosen in the study was too short to definitely determine failure of healing. It is possible that these $60 \%$ of osteotomies would also have healed after a longer observation period. As normal bone healing in mice requires about 4 weeks, a non-union should be defined as failure of healing after a time period threetimes longer than normal healing, i.e., 12 weeks. A further limitation of this model is the application of the distraction osteogenesis, which represents a highly special situation that is not comparable to the pathophysiology of nonunions in humans. Thus, the use of this model cannot be recommended to study non-union formation in mice.

In 2008 Oetgen and co-workers also reported on a non-union model in the mouse femur (Oetgen et al., 2008). The non-union was achieved by unstable fixation and an additional semi-circumferential cauterisation of the periosteum. Most probably due to the unstable fixation, this did not result in an atrophic but in a hypertrophic non-union. Thus, the model of Oetgen and co-workers may be suitable to study hypertrophic non-union formation in the femur of the mouse. Hypertrophic non-unions are generally a result of an unstable osteosynthesis and can successfully be treated with a stable osteosynthesis. Accordingly, hypertrophic non-unions do not represent a major clinical challenge. Consequently, research interests are not particularly focussed on hypertrophic non-unions, but rather on atrophic non-unions, which represent still a major clinical burden with the need for a better 
Table 4 Non-union models in the rat.

\begin{tabular}{|c|c|c|c|c|c|}
\hline Authors & $\begin{array}{l}\text { Animal/ } \\
\text { bone }\end{array}$ & Fixation & Fracture model & $\begin{array}{l}\text { Observation } \\
\text { time }\end{array}$ & $\begin{array}{l}\text { Non-union } \\
\text { rate } \\
\end{array}$ \\
\hline \multicolumn{6}{|l|}{ Large segmental defects } \\
\hline Lisignoli et al. 2002 & $\begin{array}{l}\text { rat/ } \\
\text { radius }\end{array}$ & no fixation & $5 \mathrm{~mm}$ osteotomy & 28 weeks & $100 \%$ \\
\hline Ibiwoye et al. 2004 & $\begin{array}{l}\text { rat/ } \\
\text { fibula }\end{array}$ & no fixation & $6.0 \pm 0.5 \mathrm{~mm}$ osteotomy & 6 months & $100 \%$ \\
\hline Hsu et al. 2007 & $\begin{array}{l}\text { rat/ } \\
\text { femur }\end{array}$ & $\begin{array}{l}\text { polyethylene plate } \\
\text { with screws \& cerclage }\end{array}$ & $\begin{array}{l}6 \mathrm{~mm} \text { ostetomy \& } \\
\text { periosteum elevated }\end{array}$ & 8 weeks & $100 \%$ \\
\hline Zart et al. 1993 & $\begin{array}{l}\text { rat/ } \\
\text { femur }\end{array}$ & $\begin{array}{l}\text { polyethylene plate } \\
\text { with K-wire \& cerclage }\end{array}$ & $\begin{array}{l}8 \mathrm{~mm} \text { osteotomy \& } \\
\text { peristeum elevated }\end{array}$ & 4 months & $?$ \\
\hline Ohura et al. 1999 & $\begin{array}{l}\text { rat/ } \\
\text { femur }\end{array}$ & $\begin{array}{l}\text { polyethylene plate } \\
\text { with threaded K-wire }\end{array}$ & $\begin{array}{l}5 \mathrm{~mm} \text { osteotomy \& } \\
\text { periosteum stripped }\end{array}$ & 9 weeks & $100 \%$ \\
\hline Pek et al. 2008 & $\begin{array}{l}\text { rat/ } \\
\text { femur }\end{array}$ & $\begin{array}{l}\text { metallic plate } \\
\text { and K-wire }\end{array}$ & $5 \mathrm{~mm}$ osteotomy & 5 months & $100 \%$ \\
\hline Zhang et al. 2010 & $\begin{array}{l}\text { rat/ } \\
\text { femur }\end{array}$ & radioluscent plate & $7 \mathrm{~mm}$ osteotomy & 12 weeks & $100 \%$ \\
\hline Einhorn et al. 1984 & $\begin{array}{l}\text { rat/ } \\
\text { femur }\end{array}$ & external fixator & $6 \mathrm{~mm}$ osteotomy & 12 weeks & $100 \%$ \\
\hline Hunt et al. 1996 & $\begin{array}{l}\text { rat/ } \\
\text { femur }\end{array}$ & $\begin{array}{l}\text { AO miniplate } \\
\text { and } 1.5 \mathrm{~mm} \text { screws }\end{array}$ & $4 \mathrm{~mm}$ osteotomy & 8 weeks & $100 \%$ \\
\hline Burastero et al. 2010 & $\begin{array}{l}\text { rat/ } \\
\text { femur }\end{array}$ & $\begin{array}{l}\text { PMMA-plate } \\
\text { with cerclages }\end{array}$ & $6 \mathrm{~mm}$ osteotomy & 16 weeks & $100 \%$ \\
\hline Harrison et al. 2003 & $\begin{array}{l}\text { rat/ } \\
\text { femur }\end{array}$ & external fixator & $3 \mathrm{~mm}$ osteotomy & 5 weeks & $100 \%$ \\
\hline Chakkalakal et al. 1999 & $\begin{array}{l}\text { rat/ } \\
\text { fibula }\end{array}$ & no fixation & $2 \mathrm{~mm}$ osteotomy & 8 weeks & $?$ \\
\hline \multicolumn{6}{|l|}{ Periosteal/Endosteal injury } \\
\hline Reed et al. 2003 & $\begin{array}{l}\text { rat/ } \\
\text { tibia }\end{array}$ & external fixator & $\begin{array}{l}1 \text { mm osteotomy \& } \\
\text { periosteum stripped \& } \\
\text { endosteum reamed }\end{array}$ & 16 weeks & $100 \%$ \\
\hline Hietaniemi et al. 1995 & $\begin{array}{l}\text { rat/ } \\
\text { femur }\end{array}$ & $\begin{array}{l}\text { metallic pin } \\
\text { intramedullar }\end{array}$ & $\begin{array}{l}0 \mathrm{~mm} \text { osteotomy \& } \\
\text { periosteum cauterised \& } \\
\text { endosteum reamed }\end{array}$ & 57 weeks & $100 \%$ \\
\hline Hak et al. 2006 & $\begin{array}{l}\text { rat/ } \\
\text { femur }\end{array}$ & $\begin{array}{l}\text { metallic pin } \\
\text { intramedullar }\end{array}$ & $\begin{array}{l}\text { closed fracture \& } \\
\text { periosteum cauterised }\end{array}$ & 6 weeks & $100 \%$ \\
\hline Kokubu et al. 2003 & $\begin{array}{l}\text { rat/ } \\
\text { femur }\end{array}$ & $\begin{array}{l}\text { metallic pin } \\
\text { intramedullar }\end{array}$ & $\begin{array}{l}\text { closed fracture \& } \\
\text { periosteum cauterised }\end{array}$ & 8 weeks & $100 \%$ \\
\hline Makino et al. 2005 & $\begin{array}{l}\text { rat/ } \\
\text { femur }\end{array}$ & $\begin{array}{l}\text { metallic pin } \\
\text { intramedullar }\end{array}$ & $\begin{array}{l}\text { closed fracture \& } \\
\text { periosteum cauterised }\end{array}$ & 8 weeks & $100 \%$ \\
\hline Schoen et al. 2008 & $\begin{array}{l}\text { rat/ } \\
\text { femur }\end{array}$ & $\begin{array}{l}\text { intramedullar pin } \\
\text { and diaphysal screws }\end{array}$ & $5 \mathrm{~mm}$ osteotomy & 12 weeks & $100 \%$ \\
\hline Dickson et al. 2008 & $\begin{array}{l}\text { rat/ } \\
\text { femur }\end{array}$ & external fixator & $\begin{array}{l}0 \mathrm{~mm} \text { osteotomy \& } \\
\text { periosteum cauterised \& } \\
\text { endosteum reamed }\end{array}$ & 14 weeks & $87.5 \%$ \\
\hline Kaspar et al. 2008 & $\begin{array}{l}\text { rat/ } \\
\text { femur }\end{array}$ & external fixator & $\begin{array}{l}\sim 0.5 \mathrm{~mm} \text { osteotomy \& } \\
\text { bone marrow removal \& } \\
\text { periosteum cauterised }\end{array}$ & 8 weeks & $100 \%$ \\
\hline \multicolumn{6}{|l|}{ Others } \\
\hline Chen et al. 2005 & $\begin{array}{l}\text { rat/ } \\
\text { femur }\end{array}$ & $\begin{array}{l}\text { polyethylene plate } \\
\text { with threaded K-wire }\end{array}$ & $\begin{array}{l}6 \mathrm{~mm} \text { osteotomy \& } \\
\text { infection Staph. aureus }\end{array}$ & 12 weeks & $100 \%$ \\
\hline Fujita et al. 1998 & $\begin{array}{l}\mathrm{rat} / \\
\text { tibia }\end{array}$ & no fixation & $\begin{array}{l}\text { closed fracture \& } \\
\text { surgical muscle } \\
\text { interposition }\end{array}$ & 96 weeks & $?$ \\
\hline Azad et al. 2009 & $\begin{array}{l}\text { rat/ } \\
\text { femur }\end{array}$ & $\begin{array}{l}\text { polyethylene plate } \\
\text { with screws and } \\
\text { cerclage }\end{array}$ & $\begin{array}{l}3 \mathrm{~mm} \text { osteotomy \& } \\
\text { collagen sponge \& diabetic } \\
\text { rat }\end{array}$ & 9 weeks & $100 \%$ \\
\hline Cullinane et al. 2002 & $\begin{array}{l}\text { rat/ } \\
\text { femur }\end{array}$ & external fixator & $\begin{array}{l}3 \mathrm{~mm} \text { osteotomy \& } \\
\text { external mechanical bending }\end{array}$ & 5 weeks & $\begin{array}{l}100 \% \\
\text { hypertrophic }\end{array}$ \\
\hline Schmidhammer et al. 2006 & $\begin{array}{l}\text { rat/ } \\
\text { femur }\end{array}$ & $\begin{array}{l}\text { 2.0 Mini DCP } \\
\text { and } 1.5 \mathrm{~mm} \text { screws }\end{array}$ & $\begin{array}{l}0.38 \mathrm{~mm} \text { osteotomy \& } \\
\text { latex/silicone compound } \\
\text { around the femur }\end{array}$ & 10 weeks & $83 \%$ \\
\hline
\end{tabular}


Table 5. Non-union models in the mouse.

\begin{tabular}{|l|l|l|l|l|l|}
\hline Author & $\begin{array}{l}\text { Animal/ } \\
\text { bone }\end{array}$ & Fixation & $\begin{array}{l}\text { Fracture } \\
\text { model }\end{array}$ & $\begin{array}{l}\text { Observation } \\
\text { time }\end{array}$ & $\begin{array}{l}\text { Non-union } \\
\text { rate }\end{array}$ \\
\hline Choi et al. 2004 & $\begin{array}{l}\text { mouse/ } \\
\text { tibia }\end{array}$ & $\begin{array}{l}\text { external } \\
\text { fixator }\end{array}$ & $\begin{array}{l}\text { osteotomy } \\
\text { distraction }\end{array}$ & 4 weeks & $\begin{array}{l}60 \% \\
\text { atrophic }\end{array}$ \\
\hline Kumar et al. 2010 & $\begin{array}{l}\text { mouse/ } \\
\text { tibia }\end{array}$ & $\begin{array}{l}\text { external pins+ } \\
\text { surgical sutures }\end{array}$ & $\begin{array}{l}\text { closed fracture } \\
2-3 \text { mm distraction }\end{array}$ & 16 weeks & $?$ \\
\hline Oettgen et al. 2008 & $\begin{array}{l}\text { mouse/ } \\
\text { femur }\end{array}$ & intramedullar pin & $\begin{array}{l}\text { osteotomy+ } \\
\text { periosteal cauterised }\end{array}$ & 9 weeks & $\begin{array}{l}100 \% \\
\text { hypertrophic }\end{array}$ \\
\hline Garcia et al. 2009 & $\begin{array}{l}\text { mouse/ } \\
\text { femur }\end{array}$ & $\begin{array}{l}\text { LockingMouseNail } \\
\text { interlocked }\end{array}$ & 2.0 mm osteotomy & 10 weeks & $\begin{array}{l}100 \% \\
\text { atrophic }\end{array}$ \\
\hline Garcia et al. $2008 \mathrm{~b}$ & $\begin{array}{l}\text { mouse/ } \\
\text { femur }\end{array}$ & $\begin{array}{l}\text { intramedullar pin }+ \\
\text { extramedullar clip }\end{array}$ & $\begin{array}{l}1.8 \text { mm osteotomy }+ \\
\text { periosteum resection }\end{array}$ & 15 weeks & $\begin{array}{l}100 \% \\
\text { atrophic }\end{array}$ \\
\hline
\end{tabular}

understanding of the pathophysiology and the development of novel treatment strategies.

Also in 2008, Garcia et al. described for the first time a consistently reproducible atrophic non-union model in the mouse femur using a segmental defect of $1.8 \mathrm{~mm}$ stabilised by a pin-clip technique (Garcia et al., 2008b). In this model the periosteum was additionally resected, leading to atrophic non-union formation with lack of callus formation, sclerosis of the medullar canal and scar formation in the fracture gap. There were no signs of progressive repair throughout an observation period of 15 weeks. In a subsequent study, the same authors reported on another atrophic non-union model in the mouse femur, demonstrating failure of bone healing after an observation period of 10 weeks in all animals studied. In this latter study, a segmental defect of $2.0 \mathrm{~mm}$ was stabilised with a newly developed interlocking nail (LockingMouseNail, AO Foundation, Davos, Switzerland), comparable to a human intramedullary locking nail. In contrast to the former study, the periosteum was left intact (Garcia et al., 2009). In fact, these studies demonstrate reliable models for an atrophic non-union. Currently, we recommend the LockingMouseNail model rather than the pin-clip technique due to the higher standardisation of the osteosynthesis technique and the maintenance of an intact periosteal tissue. The LockingMouseNail also allows the creation and stabilisation of a segmental defect and the implantation of new bone substitutes and tissue engineering constructs (Fig. 3). This is of special interest, because substantial efforts are made to develop new bone substitutes. These must be tested in animal models before they can be transferred to clinical application. In contrast to larger animals, the mouse model offers the possibility to study a great number of animals in a short time period to screen different candidate materials. Beside the LockingMouseNail and the pin-clip technique, non-union in the mouse may also be achieved with other osteosynthesis techniques including external fixators and plates. However, validation studies in mice using these implants are still lacking. After completion of these validation studies, those implants may also be recommended to study non-union formation and osteointegration of new bone substitutes.

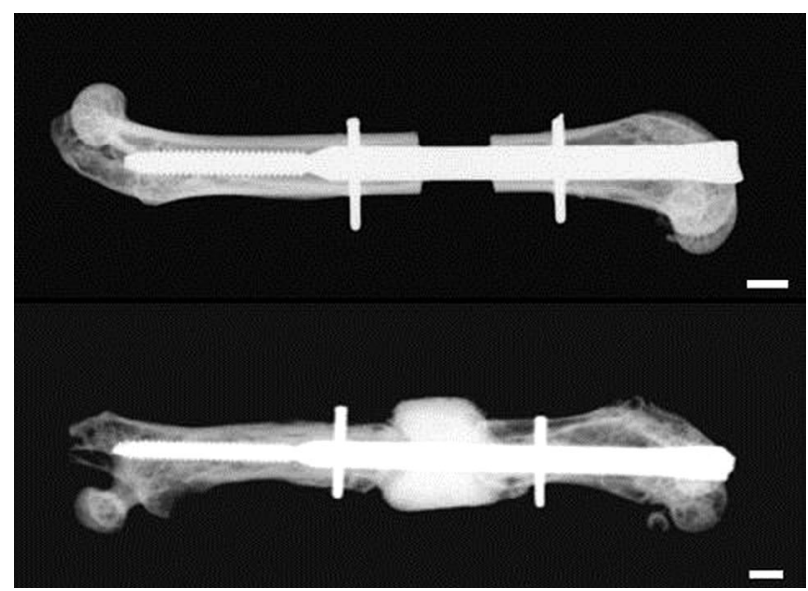

Fig. 3. Radiographs of a mouse femur (CD1 mouse) with segmental defect of $2.0 \mathrm{~mm}$ stabilised with a locking mouse nail with and without calcium phosphate bone substitute (bar represents $1.0 \mathrm{~mm}$ ).

Recently, Kumar et al. introduced a non-union model in the mouse tibia (Kumar et al., 2010). They performed a closed fracture of the tibia and stabilised this fracture with "external pins, surgical sutures and tapes". Although the 16-week observation period chosen by the authors is appropriate to study non-union formation in mice, the report lacks substantial information to judge the validity of the model, including details on the osteosynthesis technique and data on the outcome of fracture healing, i.e., the relative number of non-union formations and a radiological and histological characterisation of the nonunion, indicating whether it is hypertrophic or atrophic in nature. Besides, this model has some additional drawbacks. The authors indicate that after closed fracture a segmental defect of 2.0 to $3.0 \mathrm{~mm}$ was created by distraction of the tibia. Thus, the size of the segmental defect was not standardised and a variation of $50 \%$ may result in different outcomes of healing. Furthermore, the closed fracture of the tibia resulted in an additional fracture of the fibula in some of the animals, while in others the fibula remained unfractured. Because the fractured fibula also heals with 
Mouse

\section{Locking plate}

Locking nail

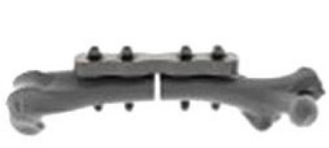

Rat
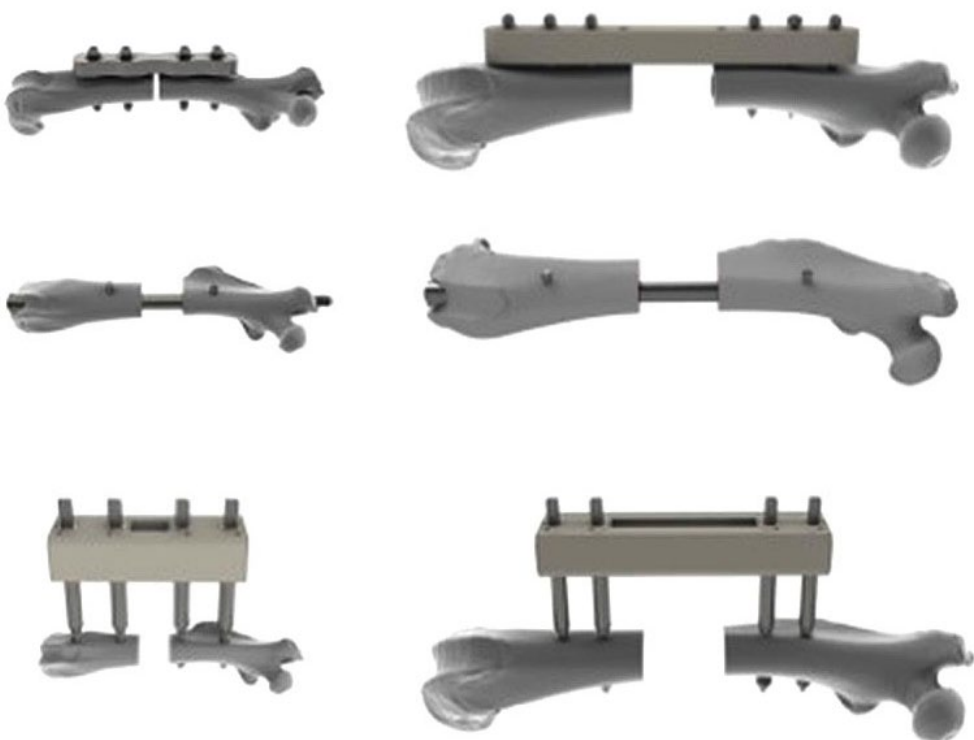

Fig. 4. Highly standardised fixation systems for the femur of rats and mice using the same principles as in humans with internal locking plates, locking nails and external fixators (Research Implant Systems, AO Foundation, Davos, Switzerland).

callus formation, this may interfere with the healing process of the tibia. Thus, this model may still have too many variabilities and can therefore not be recommended for standardised studies on non-union formation in the mouse.

\section{General recommendations to study impaired bone healing in rodents}

There are different possibilities by which bone healing can be impaired in rodent fracture models (Table 2) to study a specific healing response. In general, these techniques can all be used to study delayed healing and non-union formation in rats and mice. However, depending on the scientific question, specific approaches are more suitable than others. The aim of an animal fracture model of delayed healing and non-union formation should most closely mimic the clinical situation.

In our opinion, the best approach to mimic the clinical situation of impaired healing is the creation of a segmental defect, because a persistent fracture gap is known to be a major risk factor for non-union formation. Furthermore, bone defects are, excepting bone infections, the major clinical problem with the worst clinical outcome. Animal models studying segmental defects can be well standardised and lead reproducibly to atrophic non-unions. They are also ideally suitable to analyse new bone substitute materials and tissue engineering constructs. This will be of increasing interest for the research of next few years.

A mechanical approach also reproducibly delays fracture healing and may thus be suitable to study delayed healing and non-union formation. Modification of mechanical parameters is of particular interest to analyse the mechanisms of hypertrophic non-union formation and biomechanical aspects of impaired fracture healing. However, because hypertrophic non-unions can be treated sufficiently by a more stable osteosynthesis, we think that a mechanical approach does not fully resemble the clinical problems of failure of bone healing.

Injuries to the periosteum, the vasculature and the surrounding soft tissues are known as important risk factors that impair fracture healing and can lead to atrophic non-union formation. These models are of great interest to analyse these specific risk factors in rats and mice. Thus, they are also suitable to study new strategies for the treatment of fracture patients with soft tissue injuries. Nonetheless, we cannot recommend the use of models combining a segmental defect with resection of the periosteum, because these models do not allow for distinguishing between bone defect and soft tissue damage as the driving force for the alteration of healing. Accordingly, these models do not allow for the uncovering of distinct mechanisms of the different causes of non-union formation. Consequently, for studies that are designed to analyse the mechanisms of soft tissue injury on fracture healing, we recommend the use of models without segmental defects.

Fracture studies using transgenic animals and pharmacological interventions are suitable for analysing specific pathways of the healing cascade. However, they should not be used to analyse pathophysiological aspects of delayed healing or non-union formation in general. Furthermore, their overall value for the analysis of new treatment strategies is limited.

Surgery by itself negatively influences fracture healing. Thus, closed fracture models with intramedullary stabilisation techniques, which do not require a major surgical intervention at the fracture site may be advantageous compared to models which need surgery for the creation or the stabilisation of the fracture. However, it should be kept in mind that the creation of an osteotomy, although requiring surgery, is a highly standardised procedure, 
while the fracture pattern in closed fracture models is not as well standardised and can lead to complex fracture configurations. Thus, the choice of the model used, i.e., open or closed fracture model, may depend on the individual questions which should be answered by the experiments.

\section{Future perspectives}

During recent years, an increasing number of osteosynthesis techniques have been introduced in rats and mice. In contrast to previous more unstable stabilisation techniques, these new techniques offer a stable fixation of fractures with a high degree of standardisation. Most of the new implants used for these stabilisation techniques have been characterised biomechanically also ex vivo (Histing et al., 2009). Just like in humans, fractures in rats and mice can nowadays be stabilised by an external fixator, a locking plate or a locking nail (Fig. 4). Recently developed implants do also allow in vivo analysis of bone healing in segmental defects in rats by progressively monitoring mechanical properties (Wulsten et al., 2011).

Although sophisticated analysis techniques can nowadays be applied to mice and rats to study the process of bone healing, there are still distinct demands for future developments. Whereas a variety of analysis techniques exist to study a fractured bone ex vivo after harvesting, there is still need for new techniques to repeatedly study fracture healing in vivo. High-resolution in-vivo micro-CTs and high resolution magnetic resonance imaging (MRI) scanners may provide deeper insights into the process of fracture healing and non-union formation in the future. Such new in vivo analytical techniques would also allow a significant reduction of the number of animals necessary in future studies. However, because metallic implants are critical for the use in micro-CT and MRI scanners due to generation of artefacts, new implants which are non-metallic and non-magnetic have to be developed and experimentally introduced.

Major clinical problems, which are currently not fully addressed in rodent fracture research, are infections after fracture with delayed healing and non-union formation. Only a few studies analysed infected non-unions in rats or mice. Therefore, future studies in rats and mice should also focus on the role of infection in non-union formation. This is also of interest in order to develop new treatment strategies to control perioperative infections. Coating of implants with antibiotics might be a promising approach to reduce infections in orthopaedic surgery. The coating of implants used for fracture stabilisation in rats or mice is most probably less expensive than of implants used in large animals like sheep. Accordingly, future studies on rodent fracture healing may also include the evaluation of different new coating techniques with pharmacological products (Wildemann et al., 2004a; Wildemann et al., 2004b; Wildemann et al., 2005; Greiner et al., 2008).

Osteoporosis is a societal burden also affecting the outcome of fracture healing. Whereas most rat and mouse fracture studies have analysed diaphyseal bone healing, osteoporotic fractures are most often localised in the metaphysis. Therefore, future research should use osteoporotic animal strains and metaphyseal fracture models to study the impact of osteoporosis on fracture healing.

\section{References}

Arinzeh TL, Peter SJ, Archambault MP, van den Bos C, Gordon S, Kraus K, Smith A, Kadiyala S (2003) Allogeneic mesenchymal stem cells regenerate bone in a critical-sized canine segmental defect. J Bone Joint Surg Am 85-A: 1927-1935.

Azad V, Breitbart E, Al-Zube L, Yeh S, O'Connor JP, Lin SS (2009) rhBMP-2 enhances the bone healing response in a diabetic rat segmental defect model. J Orthop Trauma 23: 267-276.

Brownlow HC, Reed A, Simpson AH (2002) The vascularity of atrophic non-unions. Injury 33: 145-150.

Burastero G, Scarfi S, Ferraris C, Fresia C, Sessarego N, Fruscione F, Monetti F, Scarfo F, Schupbach P, Podesta M, Grappiolo G, Zocchi E (2010) The association of human mesenchymal stem cells with BMP-7 improves bone regeneration of critical-size segmental bone defects in athymic rats. Bone 47: 117-126.

Chakkalakal DA, Strates BS, Mashoof AA, Garvin KL, Novak JR, Fritz ED, Mollner TJ, McGuire MH (1999) Repair of segmental bone defects in the rat: an experimental model of human fracture healing. Bone 25: 321-332.

Chen X, Tsukayama DT, Kidder LS, Bourgeault CA, Schmidt AH, Lew WD (2005) Characterization of a chronic infection in an internally-stabilized segmental defect in the rat femur. J Orthop Res 23: 816-823.

Choi P, Ogilvie C, Thompson Z, Miclau T, Helms JA (2004) Cellular and molecular characterization of a murine non-union model. J Orthop Res 22: 1100-1107.

Claes L, Maurer-Klein N, Henke T, Gerngross H, Melnyk M, Augat P (2006) Moderate soft tissue trauma delays new bone formation only in the early phase of fracture healing. J Orthop Res 24: 1178-1185.

Claes L, Blakytny R, Gockelmann M, Schoen M, Ignatius A, Willie B (2009) Early dynamization by reduced fixation stiffness does not improve fracture healing in a rat femoral osteotomy model. J Orthop Res 27: 22-27.

Colnot C, Thompson Z, Miclau T, Werb Z, Helms JA (2003) Altered fracture repair in the absence of MMP9. Development 130: 4123-4133.

Cullinane DM, Fredrick A, Eisenberg SR, Pacicca D, Elman MV, Lee C, Salisbury K, Gerstenfeld LC, Einhorn TA (2002) Induction of a neoarthrosis by precisely controlled motion in an experimental mid-femoral defect. J Orthop Res 20: 579-586.

Den Boer FC, Patka P, Bakker FC, Wippermann BW, van Lingen A, Vink GQ, Boshuizen K, Haarman HJ (1999) New segmental long bone defect model in sheep: quantitative analysis of healing with dual energy x-ray absorptiometry. J Orthop Res 17: 654-660.

Dickson GR, Geddis C, Fazzalari N, Marsh D, Parkinson I (2008) Microcomputed tomography imaging in a rat model of delayed union/non-union fracture. J Orthop Res 26: 729-736. 
Einhorn TA, Lane JM, Burstein AH, Kopman CR, Vigorita VJ (1984) The healing of segmental bone defects induced by demineralized bone matrix. A radiographic and biomechanical study. J Bone Joint Surg Am 66: 274-279.

Follak N, Kloting I, Merk H (2005) Influence of diabetic metabolic state on fracture healing in spontaneously diabetic rats. Diabetes Metab Res Rev 21: 288-296.

Fujita M, Matsui N, Tsunoda M, Saura R (1998) Establishment of a non-union model using muscle interposition without osteotomy in rats. Kobe J Med Sci 44: 217-233.

Garcia P, Holstein JH, Histing T, Burkhardt M, Culemann U, Pizanis A, Wirbel RJ, Pohlemann T, Menger MD (2008a) A new technique for internal fixation of femoral fractures in mice: impact of stability on fracture healing. J Biomech 41: 1689-1696.

Garcia P, Holstein JH, Maier S, Schaumloffel H, AlMarrawi F, Hannig M, Pohlemann T, Menger MD (2008b) Development of a reliable non-union model in mice. J Surg Res 147: 84-91.

Garcia P, Herwerth S, Matthys R, Holstein JH, Histing T, Menger MD, Pohlemann T (2009) The LockingMouseNail-A new implant for standardized stable osteosynthesis in mice. J Surg Res 169: 220-226.

Greiner SH, Wildemann B, Back DA, Alidoust M, Schwabe P, Haas NP, Schmidmaier G (2008) Local application of zoledronic acid incorporated in a poly (D,Llactide)-coated implant accelerates fracture healing in rats. Acta Orthop 79: 717-725.

Grongroft I, Heil P, Matthys R, Lezuo P, Tami A, Perren S, Montavon P, Ito K (2009) Fixation compliance in a mouse osteotomy model induces two different processes of bone healing but does not lead to delayed union. J Biomech 42: 2089-2096.

Hak DJ, Makino T, Niikura T, Hazelwood SJ, Curtiss S, Reddi AH (2006) Recombinant human BMP-7 effectively prevents non-union in both young and old rats. J Orthop Res 24: 11-20.

Harrison LJ, Cunningham JL, Stromberg L, Goodship AE (2003) Controlled induction of a pseudarthrosis: a study using a rodent model. J Orthop Trauma 17: 11-21.

Hausman MR, Schaffler MB, Majeska RJ (2001) Prevention of fracture healing in rats by an inhibitor of angiogenesis. Bone 29: 560-564.

Hayda RA, Bosse MJ (2006) Moderators' summary: management of segmental bone defects. J Am Acad Orthop Surg 14 Suppl: S142-144.

Heppenstall RB, Brighton CT, Esterhai JL Jr, Katz M, Schumacher R (1987) Synovial pseudarthrosis: a clinical, roentgenographic-scintigraphic, and pathologic study. J Trauma 27: 463-470.

Hietaniemi K, Peltonen J, Paavolainen P (1995) An experimental model for non-union in rats. Injury 26: (10): 681-686.

Histing T, Holstein JH, Garcia P, Matthys R, Kristen A, Claes L, Menger MD, Pohlemann T (2009) Ex vivo analysis of rotational stiffness of different osteosynthesis techniques in mouse femur fracture. J Orthop Res 27: 1152-1156.

Histing T, Garcia P, Matthys R, Leidinger M, Holstein JH, Kristen A, Pohlemann T, Menger MD (2010) An internal locking plate to study intramembranous bone healing in a mouse femur fracture model. J Orthop Res 28: $397-402$.

Hollinger JO, Kleinschmidt JC (1990) The critical size defect as an experimental model to test bone repair materials. J Craniofac Surg 1: 60-68.

Hsu WK, Sugiyama O, Park SH, Conduah A, Feeley BT, Liu NQ, Krenek L, Virk MS, An DS, Chen IS, Lieberman JR (2007) Lentiviral-mediated BMP-2 gene transfer enhances healing of segmental femoral defects in rats. Bone 40: 931-938.

Hunt TR, Schwappach JR, Anderson HC (1996) Healing of a segmental defect in the rat femur with use of an extract from a cultured human osteosarcoma cell-line (Saos-2). A preliminary report. J Bone Joint Surg Am 78: 41-48.

Ibiwoye MO, Powell KA, Grabiner MD, Patterson TE, Sakai Y, Zborowski M, Wolfman A, Midura RJ (2004) Bone mass is preserved in a critical-sized osteotomy by low energy pulsed electromagnetic fields as quantitated by in vivo micro-computed tomography. J Orthop Res 22: 1086-1093.

Kaspar K, Matziolis G, Strube P, Senturk U, Dormann S, Bail HJ, Duda GN (2008) A new animal model for bone atrophic nonunion: fixation by external fixator. J Orthop Res 26: 1649-1655.

Kokubu T, Hak DJ, Hazelwood SJ, Reddi AH (2003) Development of an atrophic nonunion model and comparison to a closed healing fracture in rat femur. $\mathrm{J}$ Orthop Res 21: 503-510.

Kratzel C, Bergmann C, Duda G, Greiner S, Schmidmaier G, Wildemann B (2008) Characterization of a rat osteotomy model with impaired healing. BMC Musculoskelet Disord 9: 135.

Kumar S, Wan C, Ramaswamy G, Clemens TL, Ponnazhagan S (2010) Mesenchymal stem cells expressing osteogenic and angiogenic factors synergistically enhance bone formation in a mouse model of segmental bone defect. Mol Ther 18: 1026-1034.

Laurie SW, Kaban LB, Mulliken JB, Murray JE (1984) Donor-site morbidity after harvesting rib and iliac bone. Plast Reconstr Surg 73: 933-938.

Lindsey RW, Gugala Z, Milne E, Sun M, Gannon FH, Latta LL (2006) The efficacy of cylindrical titanium mesh cage for the reconstruction of a critical-size canine segmental femoral diaphyseal defect. J Orthop Res 24: 1438-1453.

Lisignoli G, Fini M, Giavaresi G, Nicoli AN, Toneguzzi S, Facchini A (2002) Osteogenesis of large segmental radius defects enhanced by basic fibroblast growth factor activated bone marrow stromal cells grown on non-woven hyaluronic acid-based polymer scaffold. Biomaterials 23: 1043-1051.

Lu C, Miclau T, Hu D, Marcucio RS (2007) Ischemia leads to delayed union during fracture healing: a mouse model. J Orthop Res 25: 51-61.

Lu C, Hansen E, Sapozhnikova A, Hu D, Miclau T, Marcucio RS (2008) Effect of age on vascularization during fracture repair. J Orthop Res 26: 1384-1389. 
Makino T, Hak DJ, Hazelwood SJ, Curtiss S, Reddi AH (2005) Prevention of atrophic nonunion development by recombinant human bone morphogenetic protein-7. J Orthop Res 23: 632-638.

Manigrasso MB, O'Connor JP (2004) Characterization of a closed femur fracture model in mice. J Orthop Trauma 18: $687-695$.

Manigrasso MB, O’Connor JP (2008) Comparison of fracture healing among different inbred mouse strains. Calcif Tissue Int 82: 465-474.

Mehta M, Schell H, Schwarz C, Peters A, SchmidtBleek K, Ellinghaus A, Bail HJ, Duda GN, Lienau J (2011) A 5-mm femoral defect in female but not in male rats leads to a reproducible atrophic non-union. Arch Orthop Trauma Surg 131: 121-129.

Obert L, Deschaseaux F, Garbuio P (2005) Critical analysis and efficacy of BMPs in long bones non-union. Injury 36 Suppl 3: S38-42.

Oetgen ME, Merrell GA, Troiano NW, Horowitz MC, Kacena MA (2008) Development of a femoral non-union model in the mouse. Injury 39: 1119-1126.

Ohura K, Hamanishi C, Tanaka S, Matsuda N (1999) Healing of segmental bone defects in rats induced by a beta-TCP-MCPM cement combined with rhBMP-2. J Biomed Mater Res 44: 168-175.

Oni OO (1995) A non-union model of the rabbit tibial diaphysis. Injury 26: 619-622.

Pek YS, Gao S, Arshad MS, Leck KJ, Ying JY (2008) Porous collagen-apatite nanocomposite foams as bone regeneration scaffolds. Biomaterials 29: 4300-4305.

Reed AA, Joyner CJ, Isefuku S, Brownlow HC, Simpson AH (2003) Vascularity in a new model of atrophic nonunion. J Bone Joint Surg Br 85: 604-610.

Reichert JC, Saifzadeh S, Wullschleger ME, Epari DR, Schutz MA, Duda GN, Schell H, van Griensven M, Redl H, Hutmacher DW (2009) The challenge of establishing preclinical models for segmental bone defect research. Biomaterials 30: 2149-2163.

Retzepi M, Donos N (2010) The effect of diabetes mellitus on osseous healing. Clin Oral Implants Res 21: 673-681.

Schmidhammer R, Zandieh S, Mittermayr R, Pelinka LE, Leixnering M, Hopf R, Kroepfl A, Redl H (2006) Assessment of bone union/nonunion in an experimental model using microcomputed technology. J Trauma 61: 199-205.

Schoen M, Rotter R, Schattner S, Mittlmeier T, Claes L, Vollmar B, Gradl G (2008) Introduction of a new interlocked intramedullary nailing device for stabilization of critically sized femoral defects in the rat: A combined biomechanical and animal experimental study. J Orthop Res 26: 184-189.

Strube P, Sentuerk U, Riha T, Kaspar K, Mueller M, Kasper G, Matziolis G, Duda GN, Perka C (2008) Influence of age and mechanical stability on bone defect healing: age reverses mechanical effects. Bone 42: 758-764.

Thompson Z, Miclau T, Hu D, Helms JA (2002) A model for intramembranous ossification during fracture healing. J Orthop Res 20: 1091-1098.
Utvag SE, Korsnes L, Rindal DB, Reikeras O (2001) Influence of flexible nailing in the later phase of fracture healing: strength and mineralization in rat femora. J Orthop Sci 6: 576-584.

Vashishth D (2008) Small animal bone biomechanics. Bone 43: 794-797.

Victoria G, Petrisor B, Drew B, Dick D (2009) Bone stimulation for fracture healing: What's all the fuss? Indian J Orthop 43: 117-120.

Volpon JB (1994) Nonunion using a canine model. Arch Orthop Trauma Surg 113: 312-317.

Wheeler DL, Enneking WF (2005) Allograft bone decreases in strength in vivo over time. Clin Orthop Relat Res 435: 36-42.

Wildemann B, Bamdad P, Holmer C, Haas NP, Raschke M, Schmidmaier G (2004a) Local delivery of growth factors from coated titanium plates increases osteotomy healing in rats. Bone 34: 862-868.

Wildemann B, Lubberstedt M, Haas NP, Raschke M, Schmidmaier G (2004b) IGF-I and TGF-beta 1 incorporated in a poly(D,L-lactide) implant coating maintain their activity over long-term storage-cell culture studies on primary human osteoblast-like cells. Biomaterials 25: 3639-3644.

Wildemann B, Sander A, Schwabe P, Lucke M, Stockle U, Raschke M, Haas NP, Schmidmaier G (2005) Short term in vivo biocompatibility testing of biodegradable poly(D,L-lactide) - growth factor coating for orthopaedic implants. Biomaterials 26: 4035-4040.

Wulsten D, Glatt V, Ellinghaus A, Schmidt-Bleek K, Petersen A, Schell H, Lienau J, Sebald W, Ploger F, Seemann P, Duda GN (2011) Time kinetics of bone defect healing in response to BMP-2 and GDF- 5 characterised by in vivo biomechanics. Eur Cell Mater 21: 177-192.

Zart DJ, Miya L, Wolff DA, Makley JT, Stevenson S (1993) The effects of cisplatin on the incorporation of fresh syngeneic and frozen allogeneic cortical bone grafts. J Orthop Res 11: 240-249.

Zhang ZY, Teoh SH, Chong MS, Lee ES, Tan LG, Mattar CN, Fisk NM, Choolani M, Chan J (2012) Neovascularization and bone formation mediated by fetal mesenchymal stem cell tissue-engineered bone grafts in critical-size femoral defects. Biomaterials 31: 608-620.

\section{Discussion with Reviewers}

R. Marcucio: This paper is a review of experimental fracture healing literature in order to establish definitions for union, delayed union, non-union, critical-sized defects, and segmental defects in rodents. The rationale for standardising these terms in experimental models is to establish a basis for comparison to human clinical situations, and to facilitate design of clinically relevant animal models of delayed and non-union. Is establishing standard models or gold standards really feasible?

Authors: The intention of the manuscript was not to define specific standard animal models but rather to standardise general terms like union, delayed union, non-union, 
critical-sized defects, and segmental defects that are not used consistently throughout the literature. The rationale for standardisation is not only the comparison to the human clinical situations, but primarily a comparison between different animal studies. We think that this consensus paper is a necessary step towards a uniform scientific language in rodent animal fracture studies.

R. Marcucio: What is the value in having a strict definition of a non-union time in an animal model, because this is a purely clinical outcome measure that is required for patient care. In animals we are able to determine unequivocally, and to what extent, that an injury has healed at any time after injury. So the non-union or union rate can be stated at any time point. Also, the progressive course of healing can be directly and thoroughly assessed in animal models. If progression of healing (e.g., bone and cartilage formation) has stopped before bone union, then regardless of the time point, this is a non-union. Please comment.

Authors: We do not agree that such a definition is a "purely clinical outcome measure that is required for patient care:" We are strongly convinced that such definitions are also crucial for rodent fracture studies. Choi et al. (2004) (text reference) reported e.g., on a murine non-union model using distraction osteogenesis. This model resulted in $60 \%$ non-unions after 27 days during an active distraction process. The authors did not analyse further time points and we do not know whether these $60 \%$ would have been healed after later time points. In our opinion, the authors describe $60 \%$ fractures which have not healed after 27 days. However, these $60 \%$ should not be classified as non-unions.

The reviewer indicates that "the non-union or union rate can be stated at any time point". However, a non-union is not only the absence of union. This would mean that we could create non-union models just by changing the time points of analysis. A real non-union will not heal if left alone throughout the lifetime of the animal.

The reviewer gives a definition of non-union: "If progression of healing (e.g., bone and cartilage formation) has stopped before bone union, then regardless of the time point, this is a non-union." We agree that the cessation of bone and cartilage formation is a major characteristic of non-unions and can be used to define a non-union. We already indicated this: "For the characterisation of a rodent non-union model, we recommend to analyse bone healing after 2, 4, 8, and 12 weeks in mice and after 2, 5, 10, and 15 weeks in rats to confirm the cessation of the bone healing process. However, these time points are arbitrary and other time points may also be suitable to demonstrate that there is no progressive bone healing." However, it is not always suitable to analyse fracture healing (union) in each study after multiple time points. Therefore, we defined specific time points for the determination of a non-union. According to our experience and the literature, if a fracture in the mouse has not healed by week 12, it will not heal thereafter. Although we are aware that this time point is to some extent arbitrary (as in humans), such a definition is necessary to simplify the assessment of a non-union and to reduce the number of animals as the "progression of bone and cartilage formation" can only be analysed by studying multiple time points and multiple animals. Referring solely to the progression of bone and cartilage formation to define a non-union is not suitable. Bone and cartilage formation (and regression) occur during normal fracture healing. What extent of bone and cartilage formation (or regression) would be necessary to characterise a non-union?

R. Marcucio: In the discussion of atrophic non-unions, a small segmental defect with a periosteal or endosteal injury is not recommended. Instead, a large segmental defect is preferred, because the pathophysiology of both injuries is different. However, one could easily imagine each scenario contributing to an atrophic non-union in humans. A large defect would be surgically corrected in humans, but a small gap with a periosteal injury may contribute to non-unions clinically. Please comment.

Authors: We agree that a segmental defect with an additional periosteal injury is of clinical relevance. Therefore an animal model using a segmental defect with a periosteal or endosteal injury is of clinical relevance and might be used to answer specific questions (i.e., therapeutical approach). However, the pathophysiologies of a segmental defect and a periosteal or endosteal injury are different. Therefore we do not recommend combining a segmental defect or a periosteal/endosteal injury to distinguish between both pathophysiological mechanisms.

R. Marcucio: The previous models of non-union produced by Hietaniemi et al. (1995) and Kokubu et al. (2003) (text reference) are not discussed except for a criticism of the type of stability that was used. In fact, the authors' non-union model, which is claimed to be the first, is nearly identical to these models with the exception of a different type of stabilisation. Why is the method of stability criticised here (or why is the same type of stabilisation used in humans required in rodents)? The bones did not heal and this was due to damage to the periosteum. Stability appeared to play little role in this situation. Please comment.

Authors: The non-union model of Hietaniemi et al. (1995) indeed is the first non-union model in the rat using periosteal cauterisation to impair fracture healing. The model of Kokubu et al. (2003) is comparable to the previously described model by Hietaniemi et al. (1995). In contrast to periosteal cauterisation, other authors use segmental defects in their non-union models. Although, we do not discuss the models of Hietaniemi et al. (1995) and Kokubu et al. (2003) in detail, we discuss the two major techniques to induce non-union formation (periosteal cauterisation $v s$. segmental defects). Whereas Hietaniemi et al. (1995) and Kokubu et al. (2003) presented non-union in the rat, we described for the first time a non-union model in the mouse.

With regard to the role of stability in non-union models and the question why the type of stabilisation used in humans is required in rodents, the answer is that because biomechanical factors strongly influence tissue differentiation and molecular pathways during fracture 
healing, the type of fixation is an important issue in fracture healing research. Although an unstable fixation or no fixation at all might be suitable to answer specific questions (i.e., mechanisms of endochondral bone formation), we recommend that biomechanical fixation approximates the clinical situation. This is of special interest in non-union models because there are two fundamental forms of non- unions: atrophic non-unions and hypertrophic non-unions. Hypertrophic non-unions are a result of an unstable fixation technique and are often treated sufficiently by a stable osteosynthesis. In contrast, atrophic non-unions occur after stable fixation and treatment is much more difficult due to a poor biological response of the non-unions. 